Global Journal of Human Resource Management

Vol.8, No.2, pp.58-63, June 2020

Published by ECRTD-UK

Print ISSN: 2053-5686(Print), Online ISSN: 2053-5694(Online)

\title{
THE EFFECT OF MULTI-GENERATIONAL WORKFORCE ON WORK PRODUCTIVITY IN MITSUBISHI MOTORS PHILIPPINES CORPORATION
}

\author{
Alvia Ann Viloria \\ Training Staff, Mitsubishi Motors Phililippines Corporation, Sta Rosa, Laguna, Philippines
}

\begin{abstract}
The purpose of this study is to determine the various effects of multi-generational workforce on work productivity in Mitsubishi Motors Philippines Corporation. The company would benefit first hand from the findings derived from this study in successfuly leading and managing the multi-generational workforce with the presence of inspiring leadership and a strong company culture to support the employees in working towards the company's vision and mission.
\end{abstract}

KEYWORDS: generation, productivity, Baby Boomers, Generation X, Generation Y, Generation Z

\section{INTRODUCTION}

Today's work force is continually growing for having employees in the organization with multiple generations. According to the Philippine Statistics Authority (2018) more than 60 percent of the population Fifteen years old and over are already in the labor force. On the one hand, majority of employed persons were in the age group of 25-34 years with 27.1 percent of the total employed. On the other hand, in the aged group of 35 to 44 comprised the second largest group $23.1 \%$ followed by the age group 45 to 54 years at 18.4 percent. This tendency has led to the rise of new occurrence, different generations coexisting in the same workforce.

Messarra, Karkoulian and El-Kassar (2016) mentioned, the differences between multiple generations are probable to have turned out between individuals or groups because of differences in values, opportunities, needs, qualities and workplace styles, which, in turn, could produce inharmonious actions and preferences.

Productivity is a measure of the effectiveness of a person, machine, factory, system such as in adapting inputs into useful inputs (Marsor, 2011). Productivity in general has been defined in the Cambridge International and Oxford Advance Learner's dictionaries as the rate at which goods are produced with reference to number of people and amount of materials necessary to produced it. Faced with the generational mix changes, it may also affect the productivity of the employees in the organization (Wok \& Hashim, 2013; Zhu, 2013).

Garnero, Kampelmann, and Rycx (2014) reported that diversity in age may hamper productivity in traditional industries in certain cases. Effective diversity management programs aimed at improving the economic outcome may deserve an organization's attentionOn this paper, a greater emphasis and understanding of the diverse workforce characteristics may allow the managers and supervisors to determine what drives, motivates and hinders from increasing productivity at work. 
Global Journal of Human Resource Management

Vol.8, No.2, pp.58-63, June 2020

Published by ECRTD-UK

Print ISSN: 2053-5686(Print), Online ISSN: 2053-5694(Online)

\section{RESULTS}

Productivity is designed to quantify the efficiency of a factory, machine, person, system such as in converting inputs into helpful inputs (Marsor, 2011). Regardless of the complexities that organizations appear to be competitive, innovative and productive (Soames, Brunker, \& Talgaswatta, 2011), the relationship between performance and productivity seems observable; poor performance leads to poor productivity.

Furthermore, generational differences may also affect productivity (Wok \& Hashim, 2013; Zhu, 2013). As mentioned by Johnson and Johnson (2010) describe the word generation as "a group of individuals born and living jointly who have mutual knowledge and experiences that have an effect on their attitudes, beliefs, behaviors thoughts, and values." These factors are a product of political, economic or cultural structure of the period they live (Guillot-Soulez \& Soulez, 2014).

Generations are mainly influenced by the historical events individuals experience until they become adults. By cause of the impact and power of these common events, each generation establish unique structure of attitude, belief and behavior (Giancola, 2006) and a unique identity that mold the feelings that they have for the authority and organizations (Gürsoy, Maier, \& Chi, 2008) The generational diversity changes may lead to a switch in HR programs, leadership style, strategies and changes to the workers' side of the psychological contract (van der Smissen, Schalk, \& Freese, 2013; Vasantha, 2016). An intensive exploration of an advisory group of administrative leaders for effective strategies used to enhance the productivity of a multigenerational workforce may lead to increased knowledge for other business leaders in organizations (Emrich, 2015).

According to Messarra, Karkoulian and El-Kassar (2016), the differences between the four generations are likely to have arisen between individuals or groups because of dissimilarity in expectations, needs, personalities and workplace practices which, in turn, could develop conflicting actions and preferences. The poor management of such dissimilarities or conflicts in the workplace can have unfavorable effects on the level and frequency of future conflicts and can therefore negatively affect job performance, productivity and organizational commitment.

Business leaders may shift HR practices and policies to motivate and keep the best of the generations (Messarra et al., 2016; Solaja \& Ogunola, 2016). Generations of employees will not become more similar with age. A number of researchers mentioned poor communication and other organizational issues that can lead to conflict between generationally-diverse employees (Arsenault, 2004). Work-value conflict can occur due to work-life balance issues, miscommunications, technology-use differences, and other issues among the four generations presently in the workplace (Carver \& Candela, 2008). These employee problems also encompass teamwork issues and older worker younger supervisor dyadic relationship difficulties (Collins, Hair, \& Rocco, 2009).

The different generations carry their "generation personalities" with them. If hard times hits, the generations are likely to establish themselves deeply into the attitudes and behaviors that have been instilled in them. Companies need to find ways to modify the ways that they recruit, retain, and 
Global Journal of Human Resource Management

Vol.8, No.2, pp.58-63, June 2020

Published by ECRTD-UK

Print ISSN: 2053-5686(Print), Online ISSN: 2053-5694(Online)

manage personnel in order to have a workforce that enables them to compete in a global market (Lancaster \& Stillman, 2002). Management failure to deal with generational work-value differences has been shown to result in low organizational morale, increased turnover, and which will eventually decreased profits (Carver \& Candela, 2008).

Arsenault (2004) contended that organizations will be less competitive globally if they do not capitalize on the strengths generational diversity can bring to the workplace, such as the sharing of perspectives leading to creativity and innovation. Twenge, Campbell, Hoffman, and Lance (2010) confronted that managers need to examine why and how differences between the generations affect attitudes, behaviors, competencies, and other attributes to assure their management strategies, recruitment and practices appropriately address the differences and do not lead to unforeseen consequences, such as worsening conflict in the workplace. Gentry, Deal, Griggs, Mondore, and Cox (2011) found out that managers provide workforce planning practices and human resourcemanagement strategies depend on their beliefs that work values are related to generational differences. Understanding the characteristics of each generations will benefit the managers to identify and meet the needs of their employees to successfully lead a multi-generational workforce. The solution to effectively motivate and manage four generations is relatively straightforward: it is simply that the differences of the four generations must be understood, respected, and recognized (Lancaster and Stillman, 2002).

\section{Baby Boomers}

Baby Boomers are individuals are born between 1946 - 1964. The Baby Boomers are often called to as Hippies or the Beat Generation (Mask, 2007).Born after WWII, the Baby Boom generation is the largest generation in the United States. The sheer size of this generation has caused a significant impact on societies worldwide. Historic events that have formed this generation include the space race, rock and roll, women's liberation, President John Kennedy's assassination (Society for Human Resource Management, 2010). Baby Boomers are competitive and took the concept of hard work from their parents and became "workaholics." Committed to climbing the corporate ladder of success, they believe that hard work will propel them forward in a company. Baby Boomers seek out possibilities while accepting people who will perform to their standards" (Mask, 2007).

Baby Boomers have powerful characteristics of being idealistic, driven, and optimistic. They are nourished with the desire to please, but seem judgmental of those who see things differently. This can lead to conflict in the workforce when other generations suggest new ideas or change. (Laurel, 2005).

\section{Generation X}

Generation X are individuals born between 1965-1981 and comprise approximately 34\% of today's workforce (Eastman and Liu 2012) Representatives of Generation X witnessed the development of personal computer 200 and birth of the Internet, cable TV and mobile phones and hence are more 201 technology-wise than preceding generations (Benson and Brown 2011; Burke 2004; 202 Smola and Sutton 2002; Twenge et al. 2010). They were exposed to and impacted 203 greatly by the rise of twocareer families, as well as massive layoffs, and a sharp 204 increase in the divorce rates. All these experiences established a generation that is 205 extremely adaptable, independent, resilient, to changing circumstances, and thrives 206 on change (Murphy 2007; Dowd-Higgins 2013). Generation $\mathrm{X}$ has a entirely different work ethic than their parent meaning 208 that they would like to keep a 
Global Journal of Human Resource Management

Vol.8, No.2, pp.58-63, June 2020

Published by ECRTD-UK

Print ISSN: 2053-5686(Print), Online ISSN: 2053-5694(Online)

good work-life balance and job that would offer them 209 schedule flexibility, fun (Irvine 2010) and autonomy, rather than spend as much 210 time away from family as the organization desires. They are doubtful towards 211 authority and their expectation that workplace will be able to accommodate their 212 flexibility toward how, when and where the work gets done. Their core values are 213 having fun, travel, meet people, be independent, appreciate diversity (Gursoy et al., 214 Weingarten 2009). They acknowledge that job security is a thing of the past, thus 215 they place less value on loyalty toward their employers and would take on a job 216 opportunity if it provides them with possibility to develop their skills further.

\section{Generation Y}

Generation Y are individuals born between 1980 and 1999 (Campton \& Hodge, 2006); Current labels include Millenials, Nexters, Generation www, the Digital generation, Generation E, Echo Boomers, $\mathrm{N}-$ Gens and the Net Generation. Members of the generation have labeled themselves as the NonNuclear Family generation, the NothingIs-Sacred Generation, the Wannabees, the Feel-Good Generation, Cyberkids, the Do-or-Die Generation, and the Searching-for-an-Identity Generation. This generation has been molded by parental excesses, computers (Niemiec, 2000), and dramatic technological advances. One of the most commonly reported characteristics of this generation is their comfort with technology (Kersten, 2002). Mainly, Generation Y contributes many of the characteristics of Xers. They are purported to value team work and collective action (Zemke et al., 2000), embrace diversity (The National Oceanographic and Atmospheric Office of Diversity, 2006), be optimistic (Kersten, 2002), and be adaptable to change (Jenkins, 2007). Furthermore, they seek flexibility (Martin, 2005), are independent, desire a more balanced life (Crampton \& Hodge, 2006), are multi-taskers (The National Oceanographic and Atmospheric Office of Diversity, 2006), and are the most highly educated generation. They have been characterized as demanding (Martin, 2005), and as the most confident generation (Glass, 2007). Like Xers, they are also purported to be entrepreneurial, and as being less process focused (Crampton \& Hodge, 2006).

\section{Generation Z}

Generation Z are also known as Digital Natives, Silent, and New Silent. They were born approximately between the years 2000 to the present. Unlike other generations, the members of Generation $\mathrm{Z}$ are not good listeners and they lack interpersonal skills. Communication with others normally consists of apply of the World Wide Web. As a result of the interest in new technology, the members of Generation $\mathrm{Z}$ can generally be found at locations that offer the advantage of being attached to the Web. The Generation $\mathrm{Z}$ member's interpersonal skills are dissimilar from the other generations as they are set apart and are the newest generation. Interpersonal skills are difficult to handle for this generation. They lack interpersonal skills that are needed to communicate and relate to individuals. Generation $\mathrm{Z}$ is also recognized as the "silent" generation due to technology ruling the world thus giving them the name of the "silent, the iGeneration, generation quiet, and the next generation". They take the Internet for granted and consider web sites such as Orkut, Google, and Facebook as their community. Within this community of cyber space, a person can have many acquaintances without personally meeting anyone. By being considered the quiet generation, the members of this generation do not have personal meetings with their friends that may induce to relationships. (Cook, 2015; Gouws \& Tarp, 2016; Harber, 2011; Singh, 2014) 
Global Journal of Human Resource Management

Vol.8, No.2, pp.58-63, June 2020

Published by ECRTD-UK

Print ISSN: 2053-5686(Print), Online ISSN: 2053-5694(Online)

\section{SUMMARY}

From the above-mentioned related studies, the management must invested time to make a strategies on how to manage the multi-generational workforce given that each generation has different work values, experiences and perceptions. In this manner, it has a great influence in increasing work productivity.

\section{References:}

Arsenault, P. (2004), Validating generational differences: A legitimate diversity and leadership issue. Leadership and Organization Development Journal, 12(2), 124-141. doi: $10.1108=01437730410521813$

Benson, J., \& Brown, M. (2011). Generations at work: Are there differences and do they matter? 489 International Journal of Human Resource Management, 22(9), 1843-1865.

Canaan Messarra, L., Karkoulian, S. and El-Kassar, A. (2016), "Conflict resolution styles and personality", The moderating effect of generation $\mathrm{X}$ and $\mathrm{Y}$ in a non-Western context", International Journal of Productivity and Performance Management, Vol. 65 No. 6, pp. 792-810. https://doi.org/10.1108/IJPPM- 01-2016-0014

Carver, L., \& Candela, L. (2008). Attaining organizational commitment across different generations of nurses. Journal of Nursing Management, 16(8), 984-991. doi:10.1111=j.13652834.2008.00911.x

Crampton, S. M., \& Hodge, J. W. (2006). The supervisor and generational differences. Proceedings of the Academy of Organizational Culture, Communications and Conflict, 11, 19-22

Collins, M., Hair, J., \& Rocco, T. (2009). The older-worker-younger-supervisor dyad: A test of the reverse Pygmalion effect. Human Resource Development Quarterly, 20(1), 21-41. doi:10.1002=hrdq.20006

Emrich, K. (2015). Profitability and the financial strategies of women-owned small businesses (Doctoral dissertation). Available from ProQuest Dissertations and Theses database. (UMI No. 3680364)

Eastman, J., \& Liu, J. (2012). The impact of generational cohorts on status consumption: An 546 exploratory look at generational cohort and demographics on status consumption. Journal of 547 Consumer Marketing, 29, 93-102

Garnero, A., Kampelmann, S., \& Rycx, F. (2014). The heterogeneous effects of workforce diversity on productivity, wages, and profits. Industrial Relations, 53, 430-477. doi:10.1111/irel.12064

Gentry, W., Deal, J., Griggs, T., Mondore, S., \& Cox, B. (2011). A comparison of generational differences in endorsement of leadership practices with actual leadership skill level. Consulting Psychology Journal: Practice \& Research, 63(1), 39-49. doi:10.1037=a0023015

Giancola, F. (2006). The generation gap: More myth than reality. Human Resource Planning, 29(4), 32-37.

Glass, A. (2007). Understanding generational differences for competitive success. Industrial and Commercial Training, 39, 98-103.

Gursoy, D., Maier, T. A., \& Chi, C. G. (2008). Generational differences: an examination of work 570 values and generational gaps in the hospitality workforce. International Journal of Hospitality 571 Management, 27(3), 448-458 
Global Journal of Human Resource Management

Vol.8, No.2, pp.58-63, June 2020

Published by ECRTD-UK

Print ISSN: 2053-5686(Print), Online ISSN: 2053-5694(Online)

Irvine, D. (2010). How to reward a multigenerational and culturally diverse workforce. Workspan, $58104(10), 6268$.

Jenkins, J. (2007). Leading the four generations at work. Retrieved April 15, 2008, from http://www. amanet.org/movingahead/editorial.cfm?Ed=452

Johnson, M. and Johnson, L. (2010). Generations, Inc.: From Boomers to Linksters Managing the Friction between Generations at Work. New York: American Management Association.

Jorgenson, B., Eisenberger, K., Rhoades, G. \& Cameron, B. (2014). Moving from Cognition to Action: A Control Theory Perspective. Applied Psychology 43(4), 335-398.

Kane, S. (2010). Generation y. http://legalcareers.about.com/od/practicetips/a/GenerationY.htm

Lancaster, L.C. and Stillman, D. (2002). When Generations Collide: Who they are, why they clash. How to solve the generational puzzle at work. New York: Harper Business.

Laurel, Deborah. "Bridging the Generation Gap." Laurel and Associates, Ltd.. 1-25. Print.http://www.scls.info/ce/program/documents/BridgeGenGap-3hrprog.pdf!

Marsor, R. (2011). Influence of prior acquaintance with the ratee on rater accuracy and halo. The Journal of Management Development 26 (8), 790.

Martin, C. A. (2005). From high maintenance to high productivity. What managers need to know about Generation Y. Industrial and Commercial Training, 37.

Mask, Dale. "Managing the Generation Mix in the Workplace: Tips to Manage the Generation Gap." Web. <http://searchwarp.com/swa151634.htm>.

Karkoulian, S., Messarra, L. and Sidani, M. (2009), "Correlates of the bases of power and the big five personality traits: an empirical investigation", Journal of organizational Culture, Communication and Conflict, Vol. 13 No. 1, pp. 71-82.

Murphy, S. (2007). Leading a multigenerational workforce. Washington, D.C.: AARP

Niemiec, S. (2000). Finding common ground for all ages. Security Distributing and Marketing,

Philippine Statistics Authority (2018). Current Labor Statistics. Retrieved from https://psa.gov.ph/sites/default/files/attachments/ird/specialrelease/E-CLS_2.pdf

Soames, L., Brunker, D., \& Talgaswatta, T. (2011). Competition, Innovation and Productivity in Australian Businesses. Canberra: Commonwealth of Australia

"Society for Human Resource Management." The Multigenerational Workforce: Opportunity for Competitive Success. Print.

The National Oceanographic and Atmospheric Association Office of Diversity (2006). Tips to improve the interaction among the generations: Traditionalists, boomers, X'ers and nexters. Retrieved April 15, 2008, from http://honolulu. hawaii.edu/intranet/committees/FacDevCom/ guidebk/teachtip/intergencomm.htm

Twenge, J., Campbell, S., Hoffman, B., \& Lance, C. (2010). Generational differences in work values: Leisure and extrinsic values increasing, social and intrinsic values decreasing. Journal of Management, 36(5), 1117-1142. doi:10.1177=0149206309352246

Wok, S., \& Hashim, J. (2013). Communicating and sharing working relationships with older employees. Journal of Communication Management, 17, 100-121. doi:10.1108/13632541311318729

Zemke, R., Raines, C., \& Filipczak, B. (2000). Generations at work: Managing the clash of veterans, boomers, Xers, and nexters in your workplace. New York: AMACOM. 